\title{
FIRST EXPERIENCES WITH IMPLANTATION OF PHAKIC LENSES IN CORRECTION OF MYOPIA IN R. N. MACEDONIA
}

\author{
Biljana Kostovska ${ }^{1}$, Jasmina Pluncevikj Gligoroska ${ }^{2}$, \\ Fanka Gilevska ${ }^{1}$, Zlatko Arnaudovski ${ }^{1}$, Nikica Gabric ${ }^{3}$ \\ ${ }^{1}$ Sistina ophthalmology - Specialized ophthalmology hospital, Skopje, RN Macedonia \\ ${ }^{2}$ Medical Faculty, Institute of Physiology, UKIM, Skopje \\ ${ }^{3}$ Klinika Svjetlost, Zagreb, R. Croatia
}

Corresponding author: Biljana Kostovska, Sistina ophthalmology - Specialized ophthalmology hospital, Skopje, RN Macedonia, e-mail: biljana.dr@gmail.com

\section{ABSTRACT}

Objective: Analysis of visual acuity parameters in patients with moderate to high myopia and myopic astigmatism 1 year after treatment with phakic intraocular lenses.

Material and methods: This was a retrospective study on 35 patients (52 eyes) with moderate to high myopia who were implanted with the Visian V4c phakic implantable Collamer lens (Staar Surgical, Nidau, Switzerland). Examined parameters were: uncorrected distance visual acuity (UDVA) and best corrected visual acuity (CDVA), manifest and cycloplegic refraction, intraocular pressure, and endothelial cell count. The investigated parameters were measured preoperatively, 1, 3, 6 and 12 months postoperatively. Results: In 17 patients, phakic lenses were implanted binocularly and in 18 patients monocularly. Preoperatively $34.62 \%$ of patients had CDVA from 0.9 to 1.0 . One year after the surgery $48.08 \%$ of patients had UDVA from 0.9 to 1.0 . Preoperatively $80.77 \%$ of patients had diopter range from -6.00 Dsph to -10.00 Dsph. At 1 year postoperatively $78.85 \%$ of patients were within 0.00 Dsph to -1.00 Dsph. Preoperatively, in patients with astigmatism -4 Dcyl to -2 Dcyl dominated, as opposed to significant improvement postoperatively when $94.23 \%$ had astigmatism ranging from -1.0 Dcyl to 0 Dcyl.

Conclusion: The implantation of phakic lenses demonstrated a successful postoperative outcome in the treatment of myopia and myopic astigmatism. Visual acuity and refraction show a gradual and significant improvement in visual function parameters within 1 year of lens implantation.

Keywords: myopia, astigmatism, visual acuity, diopter, lenses

\section{INTRODUCTION}

End-stage renal disease (ESRD) is an irreversPhakic intraocular lenses (pIOL) provide a safe and effective alternative for patients who may not be suitable candidates for excimer laser procedures $[1,2]$ or for patients who prefer a reversible form of vision correction with efficacy comparable to results of LASIK [3-5]. Phakic intraocular lenses are implanted into the human eye without the removal of the crystalline lens [1]. They can be implanted into either the anterior or the posterior chamber. Furthermore, it has been established that attempted corrections of high myopia with excimer laser procedures induce more higher-order aberrations, affecting vision quality 
and creating problems such as glare, halos, and ghost imaging [6] Additional advantages of intraocular procedures are: a broader range of treatable ametropia, faster visual recovery, more stable refraction, and better visual quality.

In the absence of any contraindications, pIOL implantation is the preferred best approach for young patients with moderate to high refractive errors and in those cases where there is a contraindication to a corneal refractive procedure (e.g., thin corneas). The advantages are that pIOL implantation does not affect accommodation and the procedure is reversible [2,10-12]. The complications relating to $\mathrm{pIOLs}$ can, at times, be more disabling than those from keratorefractive surgery. Corneal decompensation, glaucoma, cataract formation, dyscoria, uveitis, and endophthalmitis are potential complications after pIOL implantation [13]. Nevertheless, in comparison with LASIK for high myopia, pIOLs are highly favorable in terms of patient satisfaction and visual acuity.

The Visian Implantable Collamer Lens (ICL; STAAR Surgical, Nidau, Switzerland), a posterior chamber phakic intraocular lens (pIOL), is useful for the correction of moderate to high ametropia over the long term [1-6]. However, undesirable complications such as lens opacification, endothelial cell density (ECD) loss, increased intraocular pressure, and inflammation have been reported after pIOL implantation [3,5,7-9]

Several studies report that UDVA was equal to or better than preoperative CDVA in almost all patients $(98 \%)$ with high myopia. No patients had postoperative CDVA worse than preoperative CDVA $[9,10,11]$. Meta-analysis of the effectiveness and safety of intraocular lenses during the last decade of application of this method show similarly satisfactory results and significant improvement in vision and quality of life [12].

The purpose of this study was to analyze visual acuity parameters in patients with moderate to high myopia and myopic astigmatism 1 year after the implantation of ICL.

\section{MATERIAL AND METHODS}

\section{Study design}

This was a retrospective study at Sistina Eye Hospital in Skopje in the period from May 2018 to May 2019. 35 patients (52 eyes) with moderate to high myopia and astigmatism were enrolled. The study was approved by the Ethics committee at the Sistina Eye Hospital. The tenets of the Helsinki agreement were respected throughout. Informed consent was obtained from all patients after details of the procedures, the risks and benefits were fully explained both verbally and in writing.

Inclusion criteria were patients from 21 to 41 years, with myopia from -3 Dsph to -10 Dsph and astigmatism up to -4 Dcyl., anterior chamber depth $>3 \mathrm{~mm}$, stable endothelial cells more than $2500 \mathrm{~mm} 2$ cells. The recommendations were given by the manufacturer of the phakic lenses (STAAR Surgical AG, Nidau, Switzerland). Patients with corneal pathology or anterior and posterior segment disease were not included in this study.

In this study we investigated the following parameters: uncorrected (UDVA) and best corrected visual acuity (CDVA) recorded in Snellen decimal lines, manifest and cycloplegic refraction, intraocular pressure with non-contact tonometer, (Auto Non-Contact Tonometer, Reichert Inc., Buffalo, NY, USA), corneal topography (Wavelight, Allegro Oculyzer, Erlangen, Germany), and endothelial cells with a specular microscope (Costruzione Strumenti Oftalmici $\mathrm{CSO}$, Florence. Italy). The length of the phakic lens is measured through the diameter of the cornea (WTW - white to white) with pentacam or manually by caliper.

In each case, the ICL/TICL dioptric power was calculated with the use of the software provided by the manufacturer. The calculation was based on the formula developed by van der Heijde [21,22]. The calculation was based on the patient's refraction at the spectacle plane, the back-vertex distance, the corneal anterior surface keratometric dioptric power at its apex, and the central ACD $[1,9]$. The selected ICL/TICL overall diameter depends on the ciliary sulcus diameter to provide stability with no excess of compression forces on the sulcus and allow correct vaulting. Excessive vaulting $(>750 \mathrm{~mm})$ due to a TICL that is too large may cause pupillary block, pigmentary dispersion, or angle closure glaucoma. Insufficient vaulting $(250 \mathrm{~mm})$ due to a TICL that is too small increases the risk of cataractogenesis. This is the result of any contact between the posterior surface of the implant and the anterior surface of the crystalline lens $[14,15]$.

The internal diameter of the ciliary sulcus was measured by ultrasound biometry or approx- 
imated by horizontal white-to-white (WTW) measurement obtained manually using a caliper or automatically by topographic or some other biometric device.

The TICL diameter is oversized by 0.5 to $1.0 \mathrm{~mm}$ from the WTW measurements in myopic eyes and the same length or oversized 0.5 $\mathrm{mm}$ in hyperopic eyes. In this study, we are only concerned with myopic cases. However, recent studies demonstrated that there is no anatomical correspondence between external measurements and internal dimensions.

Therefore, using the WTW distance alone may not be the ideal route to predict the angle or sulcus size $[2,9,16]$.

\section{SURGICAL TECHNIQUE}

Correct loading of the ICL/TICL in the cartridge and the injector is essential for correct and easy implantation. Using a modified McPherson forceps with long, blunt, curved tips, the TICL was grasped and checked under the operating microscope. The ICL/TICL has 2 tiny holes on the footplates (distal right and proximal left) that allow correct anterior-posterior orientation. The cartridge was filled with an ophthalmic viscosurgical device (OVD; Amvisc, Bausch \& Lomb, New York). The TICL was loaded with the dome facing upward, being particularly careful over the haptic position to avoid tearing. A piece of soft material, the STAAR foam tip, was positioned to protect the TICL from contact with the plunger of the shooter. Before surgery, at the slit lamp, the horizontal axis of the cornea was marked with a 15-degree knife at the corneal-limbal junction at the 3 and 90 'clock positions (0 and 180 degrees). Full pharmacological mydriasis was essential for uneventful implantation. To mark the TICL axis on the cornea, a Mendez ring, graduated in 10-degree steps, was placed on the cornea (with the 0 degree - 180 degrees setting) aligned to coincide with corneal markings made on the slit lamp, and the desired TICL axis was marked on the cornea with an ink marker. The first paracentesis incision was created, and the OVD was installed into the anterior chamber to protect the corneal endothelium and crystalline lens from surgical trauma. Then, the second paracentesis incision was performed, followed by a $3.2 \mathrm{~mm}$ clear corneal incision placed either temporally or superiorly depending on the axis of corneal astigmatism. The cartridge was inserted, and the TICL was carefully injected. It is essential to control TICL unfolding and to twist the bevel right or left to ensure the correct orientation of the lens. Finally, the haptics were gently pushed under the iris with a blunt spatula. After inspection of the lens centration and axis position, acetylcholine was injected into the anterior chamber to induce pupil constriction. Irrigation/aspiration of the OVD was meticulously performed throughout eye. Refraction, UDVA, CDVA, intraocular pressure values, endothelial cells and possible complications in the course of 1 year were monitored. The examined parameters were measured preoperatively and in 4 control examinations for one year following the intervention, after 1 month, 3, 6, and 12 months.

\section{STATISTICAL ANALYSIS}

At present, several urine biomarkers have been All data were collected on a Microsoft Office Excel 2007 spreadsheet for statistical analysis. For parameters of UDVA, CDVA, spherical refraction and cylindrical refraction descriptive statistics was used (mean value, standard deviation, $\pm 95.00 \% \mathrm{CI}$; Median; and range). The differences between the values of the analyzed parameters in relation to each other, preoperatively and postoperatively after 1, 3, 6 months, and 1 year, were analyzed using Friedman ANOVA Chi Sqr. / p. The categories of visual acuity, spherical correction and cylindrical correction are presented in percentage $(\%)$. Differences in the findings, preoperatively and postoperatively, were the following: preoperative CDVA and 1 year postoperative UDVA, preoperative spherical refraction and 1 year postoperative spherical refraction, preoperative, and 1 year postoperative cylindrical refraction. These differences were analyzed using Fisher's Exact Test/Monte Carlo Sig. (2-sided) (p). Significance is determined by $\mathrm{p}<0.05$.

\section{RESULTS}

In this study, 17 patients had bilateral lens implants and 18 patients had an implant in only 
one eye. There were 10 men and 25 women in the study. Preoperative evaluation, operative procedure, and regular follow ups, as scheduled, were performed with all patients within a period of 12 months, without delay. There was no patient loss during the study.

\section{VISUAL ACUITY}

Figure 1 shows preoperative CDVA and postoperative UDVA over the course of one year. Preoperatively, patients were dominantly with a CDVA from 0.9 to $1.0,34.62 \%(\mathrm{~N}=18)$. Postoperatively, after 1 year, the highest percent of patients, $48.08 \%(\mathrm{~N}=25)$, were with the same visual acuity, 0.9 to 1 . UDVA increased significantly $(p<0.001)$ during the one year follow up compared to CDVA preoperatively.

\section{SPHERICAL REFRACTION}

Preop and postop spherical correction is shown in table 1. For Friedman ANOVA Chi Sqr. $(\mathrm{N}=52, \mathrm{df}=4)=130,18$ and $\mathrm{p}<0.001(\mathrm{p}=$ $0.000)$, there is a significant difference between preoperative and postoperative dioptric values. The mean preoperative dioptric range (Dsph) of myopic patients was -7.75 Dsph \pm 1.91 Dsph. In the postoperative period, significantly lower values of the spherical dioptric range were registered, with the mean value being $-0.15 \mathrm{Dsph} \pm$ $0.32 \mathrm{D}$ after one year.

Figure 2 presents the change in spherical diopter power in the period of one year follow up. Preoperatively, the dioptric power ranged from -6 sph to -10 Dsph in $80.77 \%$ of the eyes $(\mathrm{N}$ $=42$ ). Postoperatively, after 1 year, the dioptric power ranged from -1 Dsph to $0 \mathrm{Dsph}$ in $78.85 \%$ of the eyes $(\mathrm{N}=41)$.

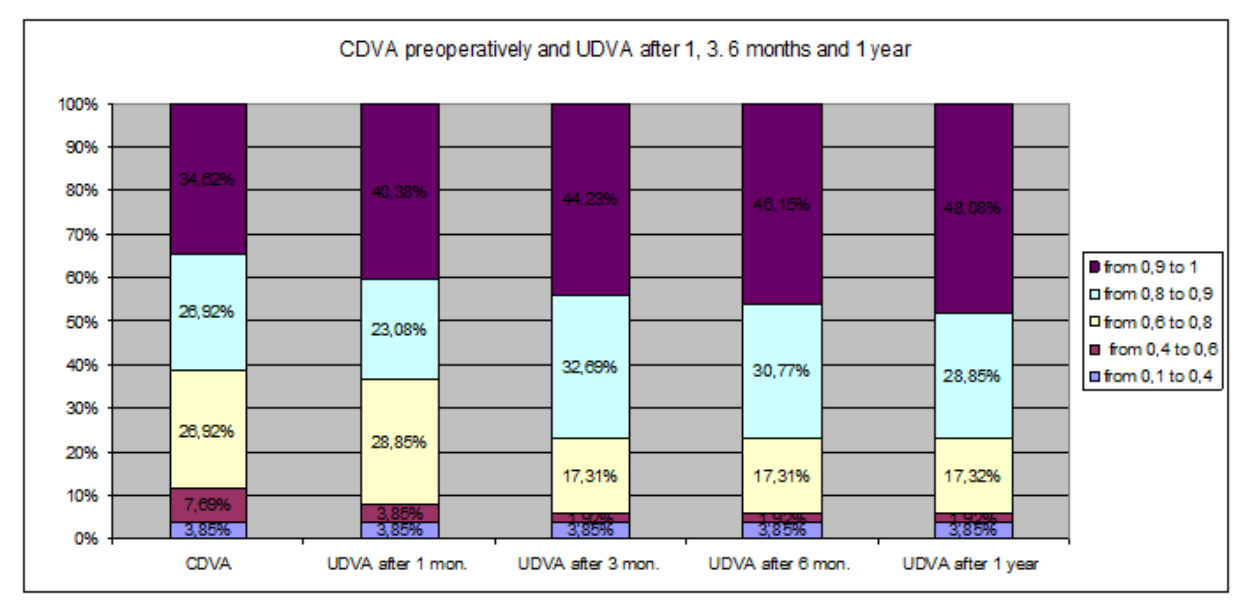

Figure 1. CDVA preoperatively and UDVA postoperatively after 1, 3, 6 months, and 1 year

Table 1. Spherical dioptric range preoperatively and during the postoperative period after 1, 3, 6 and 12 months

\begin{tabular}{|c|c|c|c|c|c|c|c|c|}
\hline Variable & Valid N & Mean & $\begin{array}{c}\text { Confidence } \\
-95.00 \%\end{array}$ & $\begin{array}{c}\text { Confidence } \\
+95.00 \%\end{array}$ & Median & Minimum & Maximum & $\begin{array}{c}\text { Std. } \\
\text { dev. }\end{array}$ \\
\hline \hline Dsph & 52 & -7.75 & -8.28 & -7.22 & -8.00 & -10.00 & -3.25 & 1.91 \\
\hline \hline Dsph after 1 mon. & 52 & -0.18 & -0.30 & -0.06 & -0.25 & -0.75 & 0.75 & 0.43 \\
\hline Dsph after 3 mon. & 52 & -0.18 & -0.29 & -0.08 & -0.25 & -0.75 & 0.75 & 0.37 \\
\hline Dsph after 6 mon. & 52 & -0.21 & -0.30 & -0.12 & -0.25 & -0.75 & 0.75 & 0.33 \\
\hline \hline Dsph after 1 year. & 52 & -0.15 & -0.24 & -0.07 & -0.25 & -0.50 & 0.50 & 0.32 \\
\hline
\end{tabular}




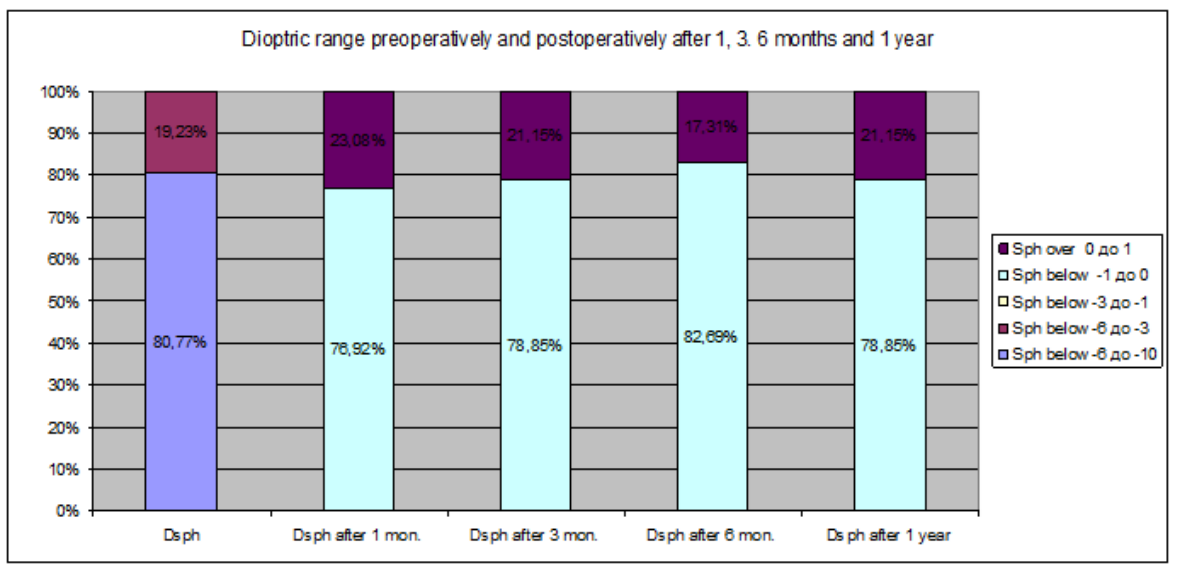

Figure 2. Percentage stratification of different categories of spherical correction (Dsph) preoperatively and postoperatively after 1, 3, 6 months and 1 year

\section{CYLINDRICAL REFRACTION}

There is a significant change in the power of the cylinder in the period of one year (table 2 and Figure 3). The value of the preoperative cylindrical correction (Dcyl) varies within the range of $-1.86 \pm 1.18$ Dcyl. During all postoperative examinations, the average value of the cylindrical correction was significantly lower, and in the period after 6 and after 12 months it has the same value, $-0.25 \pm 0.25$ Dcyl. Astigmatism change was calculated with Friedman ANOVA Chi Sqr. $(\mathrm{N}=52$, df $=4)=193.87$ and $\mathrm{p}<0.001$ $(p=0.000)$, showing a significant difference in the relation. Preoperatively, astigmatism within a range of -4 Dcyl to -2 Dcyl was found in $32.69 \%$ of the patients and postoperatively, most of the patients were with dioptric range from -1 Dcyl to 0 Dcyl, $94.23 \%(\mathrm{~N}=49)$.

Table 2. Astigmatism (Dcyl.) preoperatively and post. after 1, 3, 6 months and 1 year

\begin{tabular}{|c|c|c|c|c|c|c|c|c|}
\hline Variable & $\begin{array}{c}\text { Valid } \\
\mathrm{N}\end{array}$ & Mean & $\begin{array}{c}\text { Confidence } \\
-95.00 \%\end{array}$ & $\begin{array}{c}\text { Confidence } \\
+95.00 \%\end{array}$ & Median & Minimum & Maximum & $\begin{array}{c}\text { Std. } \\
\text { dev. }\end{array}$ \\
\hline PREOP & 52 & -1.86 & -2.19 & -1.53 & -2.00 & -4.00 & 0.00 & 1.18 \\
\hline POSTOP 1 & 52 & -0.30 & -0.38 & -0.22 & -0.25 & -0.75 & 0.50 & 0.30 \\
\hline Dcyl after 3 mon. & 52 & -0.31 & -0.38 & -0.25 & -0.25 & -0.75 & 0.25 & 0.23 \\
\hline Dcyl after 6 mon. & 52 & -0.27 & -0.34 & -0.20 & -0.25 & -0.75 & 0.50 & 0.25 \\
\hline Dcyl after 1 year & 52 & -0.25 & -0.32 & -0.17 & -0.25 & -1.00 & 0.50 & 0.25 \\
\hline
\end{tabular}

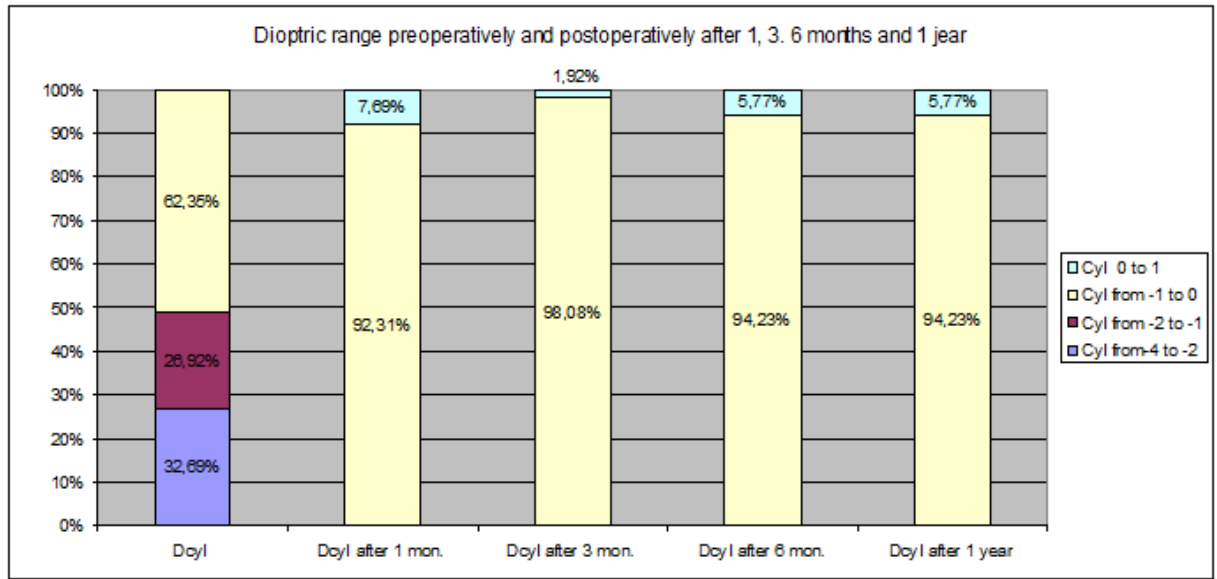

Figure 3. Stratification of cylindrical dioptric range (Dcyl) preoperatively and postoperatively after 1, 3,6 months and 1 year 


\section{INTRAOCULAR PRESSURE}

There is no significant difference in the IOP values before and after the treatment $-\mathrm{Z}=$ 3.25 and $p<0.01(p=0.001)$. Postoperative IOP values after 1 year are similar with preoperative IOP values.

Table 3. Intraocular pressure (IOP) preoperatively and 12 months postoperatively

\begin{tabular}{|c|c|c|c|c|c|c|c|}
\hline $\begin{array}{l}\frac{0}{\pi} \\
\frac{\pi}{\pi} \\
\frac{\pi}{\nu}\end{array}$ & $\stackrel{\mathbb{E}}{\Sigma}_{\Sigma}^{ \pm}$ & 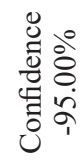 & 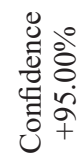 & 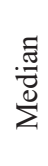 & 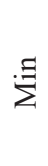 & 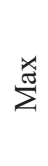 & $\hat{\sim}$ \\
\hline IOP preop. & 15.56 & 15.07 & 16.05 & 16 & 10 & 20 & 1.76 \\
\hline $\begin{array}{c}\text { IOP after } 1 \\
\text { year }\end{array}$ & 14.27 & 13.58 & 14.96 & 14 & 9 & 20 & 2.47 \\
\hline
\end{tabular}

\section{ENDOTHELIAL CELL COUNT DENSITY}

For $Z=5.83$ and $p<0.01(p=0.001)$ the value of endothelial cells postoperatively after 1 year is significantly lower than the value of endothelial cells preoperatively $(2.3 \%)$.

\section{DISCUSSION}

This is the first study performed in North Macedonia in which the results of myopia correction in patients with implanted phakic lenses are monitored and controlled. The results shown confirm the success of refractive correction with ICL lenses in patients with moderate to high myopia and myopic astigmatism.

Measures of clinical effectiveness include postoperative uncorrected distance visual acuity (UDVA), manifest refractive spherical equiv- alent (MRSE), refractive predictability, and refractive stability.

\section{Visual Acuity}

The results of our research showed that, during all control examinations, there is an improvement in visual acuity when compared the CDVA and UDVA, from the first month after operation until the 12 months after. The improvement was between $5 \%$ and $15 \%$ in each group of eyes. Before the surgery $34.62 \%$ of the eyes had CDVA values between 0.9 to 1.0 . At 1 year postoperation the number of eyes with UDVA values of 0.9 to 1.0 increased to $48.08 \%$, while another $30.77 \%$ of the eyes reached 0.8 to 0.9 .

Our results are in line with the results of the American Academy of Ophthalmology for refractive surgery where an improvement in visual acuity to 0.9 to 1.0 in $60 \%$ of patients after 1 year was noted, and $92.5 \%$ of patients could read 0.5. [14].

Sanders et al. reported improved and stable visual acuity, with $83.1 \%$ of patients with a UDVA of $20 / 20$ or better. The postoperative UDVA was within one line of preoperative CDVA in $95 \%$ of the eyes [15].

In a similar study among the Chinese population which investigated vision-related daily activities after V4c-ICL implantation, the UDVA values proved significantly better at 3 months after surgery $(p<0.001)[9]$. The mean corrected distance visual acuity (CDVA) in patients undergoing implantation of ICL V4C was $0.89 \pm 0.30$ versus UDVA, $1.00 \pm 0.27$, postoperatively [2]. The study among Iranian patients showed that half of the treated eyes (50\%) had a UDVA of $20 / 20$ or better, and 27 eyes $(96 \%)$ had a UDVA of 20/40 or better [16]. A comparison of UDVA in young myopes after 13 months of ICL implantation to preoperative CDVA indicated that 27 eyes $(26 \%)$ had better postoperative UDVA and 61 eyes $(59 \%)$ had UDVA equivalent to the preoperative CDVA [17].

Table 4. Endothelial cells preoperatively and 12 months after surgery

\begin{tabular}{|c|c||c|c|c|c|c|c|c|}
\hline Variable & Valid N & Mean & $\begin{array}{c}\text { Confidence } \\
-95.00 \%\end{array}$ & $\begin{array}{c}\text { Confidence } \\
+95.00 \%\end{array}$ & Median & Minimum & Maximum & $\begin{array}{c}\text { Std. } \\
\text { dev. }\end{array}$ \\
\hline ECD preop & 52 & 2456.65 & 2425.84 & 2487.47 & 2442 & 2310 & 2931 & 110.69 \\
\hline ECD postop & 52 & 2399.00 & 2367.53 & 2430.47 & 2380 & 2245 & 2847 & 113.04 \\
\hline
\end{tabular}




\section{Spherical refraction}

The most remarkable variable of refractive error, the amount of spherical refraction, showed a significant improvement from an average of -7.75 Dsph preoperatively to -0.15 Dsph one year after the surgery. During one year of monitoring, the mean spherical equivalent (MRSE) improved, (i.e. decreased) to values of -0.18 Dsph in the first three months after surgery, and remained stable for the entire period of 12 months. In the largest percentage of our patients $(80.77 \%)$ myopia before the correction was between $-6.0 \mathrm{D}$ to $-10 \mathrm{D}$, while after correction by implantation of phakic lenses the dioptric range from -1.0 to 0 was predominant $(78.58 \%$ of patients). This result is similar to the result of a study by Alfonso et al. where a desired \pm 0.5 Dsph was present in $94 \%$ of patients [18]. In $21 \%$ of our eyes, the postoperative value of spherical refraction was between 0 and $+1 \mathrm{D}$. The spherical refractive error improved from the baseline mean value of $-13.31 \pm 4.34 \mathrm{D}$ to -0.67 \pm 1.29 D [2]. Very successful clinical outcomes were obtained among the Indian population, where $94 \%$ of the eyes achieved a postoperative manifest spherical equivalent within $\pm 0.5 \mathrm{D}$, one year after ICL implantation [19]. Fernandez et al. in 2017 noticed $90.70 \%$ residual spherical refraction of $\pm 0.5 \mathrm{Dsph}$ after 12 months in 184 patients [20].

\section{Cylindrical refraction}

Regarding the need for the correction of astigmatism, preoperative astigmatism values from -2 to -4 Dcyl $(40.38 \%)$ were dominant in our study. Postoperatively in $94.23 \%$ of the eyes, a significantly lower diopter from -1.0 to 0 Dcyl was registered. Eyes with the preoperative value of cylindrical refraction from -2.0 Dcyl to -1.0 Dcyl achieved complete correction of astigmatism. These results are similar to the results of Sanders et al., where the group's values ranged from 0 to -1.0 Dcyl, representing 91.4\% [15].

The correction of the cylindrical refraction showed very successful results, from preoperative mean values of -1.86 Dcyl to a stable average of -0.25 Dcyl, with approximately the same value throughout the postoperative year.

\section{Intraocular pressure}

Values of intraocular pressure were stable during 1 year of follow ups. In the study, 52 eyes were implanted with the ICL (V4c model). There was no significant difference in IOP during the follow-up period [21]. The IOP in 31 Chinese patients after ICL implantation was $15.15 \pm 2.57$ $\mathrm{mmHg}$, which was not significantly different regarding the preoperative value [22]. Gonzalez-Lopez et al. reported that no eye in their series of 100 eyes had an IOP greater than 30 $\mathrm{mmHg}$ at any postoperative measurement [23].

Before the surgery, the mean IOP in our study was $15.56 \mathrm{mmHg}$, and after the surgery it lowered down to $14.27 \mathrm{mmHg}$. During the course of follow up, there has not been any increase of the IOP among patients in our study. Elevation of IOP could happen in the early postoperative period due to residual viscoelastic in the anterior chamber or because of angle closure due to the position of ICL haptics and development of pupillary block. In the MICL PAS clinical trial, the incidence of IOP elevation was $3.2 \%$, with 17 cases of pupillary block out of the 526 eyes that received the implant [24].

\section{Endothelial cell count density (ECD)}

Endothelial cell count was regularly assessed in the postoperative period. It is important to take into consideration the expected age-related endothelial loss, which could be $0.6 \%$ per year [25]. Endothelial cell loss in our study is $2.3 \%$, and is significantly lower than the study by Moya et al. [26], which had endothelial cell loss at $6.4 \%$ in the first year. We expect that the ECD will be lower in the next years of follow ups. This is not measured in our study. In the study of Moya et al. the second-year decrease was $1.5 \%$. ECD value remained unchanged over the follow-up period of 12 months in the high myopic patients who underwent ICL-V4c implantation [27]. The comparison between the influences on the ECD after implantation of three different phakic intraocular lenses showed a certain level of cell loss, from the lowest rate of $3.5 \%$ (ICLs) to the highest rate of $25 \%$ in Veriflex pIOLs [28].

\section{Complications}

The most common complications are subcapsular anterior lens clouding and glaucoma [29]. We do not have any patients with complications in our study. Several studies have shown minimal incidence of cataracts (less than 3\%) after 2 years of implantation, twice the risk of implantation of the ICL-V4b and other previous 
models of phakic lens [30,31]. Parker's review of the study showed 67 preclinical and clinical studies of more than 2000 eyes over 12 months. High visual acuity, refractive predictability, and stability demonstrate the effectiveness of the ICL implantation [23].

\section{CONCLUSION}

The implantation of phakic lenses has shown to have a successful postoperative outcome in the treatment of moderate to high myopia and myopic astigmatism. Visual acuity, spherical and cylindrical refraction showed prompt, significant improvement and stability in visual function parameters within 1 year of lens implantation.

\section{REFERENCES}

1. Kohnen T, Strenger A, Klaproth OK. Basic knowledge of refractive surgery. Deutsches Arzteblatt International, 2008;105:163-172.

2. Niu L, Miao H, Han T, et al. Visual outcomes of Visian ICL implantation for high myopia in patients with shallow anterior chamber depth. BMC Ophthalmology (2019) 19:121.

3. Oakley CL, Nigro MA, Vote BJ. Fifty-year follow-up and Strampelli anterior chamber intraocular lens. GMS Ophthalmol Cases. 2015;5:Doc 06.

4. Sanders DR, Doney K, Poco M. ICL in Treatment of Myopia (ITM) Study Group. United States Food and Drug Administration clinical trial of the implantable collamer lens (ICL) for moderate to high myopia: three-year follow-up. Ophthalmology 2004;111: 1683-92

5. Kohnen T, Knorz MC, Neuhann T;German Ophthalmological Society;Professional Association of German Ophthalmologists.Evaluation and quality assurance of refractive surgery procedures by the German Ophthalmological Society and the Professional Association of German Ophthalmologists [in German]. Ophthalmologe.2007;104(8):719-726.

6. Huang D, Schallhorn SC, Sugar A, et al. Phakic Intraocular Lens Implantation for the Correction of Myopia. A Report by the American Academy of Ophthalmology. Ophthalmology. 2009;116(11):2244-2258.

7. Fernández-Vega-Cueto L, Lisa $\mathrm{C}$, Esteve-Taboada JJ, Montés-Micó R, Alfonso JF. Implantable collamer lens with central hole: 3-year follow-up. Clin Ophthalmol. 2018;12:2015-2029 https://doi.org/10.2147/OPTH.S171576

8. Wang X, Zhou X. Update on treating high myopia with implantable collamer lenses. Asia Pac J Ophthalmol (Phila). 2016;5(6):445-449. doi:10.1097/APO.0000000000000235

9. Kobashi H, Kamiya K, Igarashi A, et al. Longterm quality of life after posterior chamber phakic intraocular lens implantation and after wavefront-guided laser in situ keratomileusis for myopia. J Cataract Refract Surg. 2014;40(12):201924.

10. Liu T, Linghu S, Pan L, et al. Effects of V4cICL implantations on myopic patients vision-related daily activities. Journal of Ophthalmology, 2016;2016:5717932

11. Miao H, Chen X, Tian M. et al. Refractive outcomes and optical quality after implantation of posterior chamber phakic implantable collamer lens with a central hole (ICL V4c). BMC Ophthalmol. 2018; 18(1):141

12. Packer M. Meta-analysis and review: effectiveness, safety and central port design of the intraocular collamer lens. Clinical Ophthalmology, 2016; 10: 1069-1077

13. Medical Advisory Secretariat. Phakic intraocular lenses for the treatment of refractive errors: an evidence-based analysis. Ont Health Technol Assess Ser. 2009;9(14):1-120. Epub 2009 Oct 1. PMID: 23074518; PMCID: PMC3377525.

14. Sanders DR, Vukich JA, Doney K, Gaston M; Implantable Contact Lens in Treatment of Myopia Study Group. U.S. Food and Drug Administration clinical trial of the Implantable Contact Lens for moderate to high myopia. Ophthalmology. 2003 Feb;110(2):255-66. doi: 10.1016/ s0161-6420(02)01771-2. PMID: 12578765.

15. Sanders DR, Schneider D, Martin R, et al. Toric Implantable Collamer Lens for moderate to high myopic astigmatism. Ophthalmology. 2007;114(1):5461

16. Ghoreishi M, Preyman A, Jafarzadeh Z, et al. Visual outcomes of toric implantable collamer lens for correction of compound myopic astigmatism. Iranian J of Ophthalmology, 2013, 25(2):155-162

17. Dougherty PJ, Priver T. Refractive outcomes and safety of the implantable collamer lens in young low to moderate myopes. Clinical ophthalmology. 2017, 11:273-277

18. Alfonso JF, Fernández-Vega L, Lisa C, Fernandes P, González-Méijome JM, Montés-Micó R. Collagen copolymer toric posterior chamber phakic intraocular lens for myopic astigmatism, Journal of Cataract \& Refractive Surgery: 2010 Jun;36(6):906-16

19. Sachdev GS, Singh S, Ramamurthy S, et al. Comparative analysis of clinical outcomes be- 
tween two types of posterior chamber phakic intraocular lenses for correction of myopia and myopic astigmatism. Indian J of Ophthalmology, 2019, 67(7):1061-1065

20. Fernández-Vega-Cueto L, Lisa C, Esteve-Taboada JJ, Montés-Micó R, Alfonso JF. Implantable collamer lens with central hole: 3-year follow-up. Clin Ophthalmol. 2018; 12:2015-2029https://doi.org/10.2147/OPTH. S 171576

21. Higueras-Esteban A, Ortiz-Gomariz A, Gutiérrez-Ortega $\mathrm{R}$, et al. Intraocular pressure after implantation of the Visian Implantable Collamer Lens with CentraFLOW without iridotomy. Am J Ophthalmol. 2013 Oct;156(4):800-5.

22. Niu L, Miao H, Han T, Ding L, Wang X, Zhou $\mathrm{X}$. Visual outcomes of Visian ICL implantation for high myopia in patients with shallow anterior chamber depth. BMC Ophthalmol. 2019;19(1):121. Published 2019 May 29.doi:10.1186/s12886-019-1132

23. Gonzalez-Lopez F, Bilbao-Calabuig R, Mompean B, et al. Intraocular pressure during the early postoperative period after 100 consecutive implantations of posterior chamber phakic intraocular lenses with a central hole. J Cataract Refract Surg. 2013;39(12):1859-1863

24. Packer, Mark., The Implantable Collamer Lens with a central port: review of the literature. Clinical Ophthalmology. Volume 12. 2427-2438. 10.2018; OPTH.S188785

25. Bourne WM, Nelson LR, Hodge DO. Central corneal endothelial cell changes over a ten-year period. Invest Ophthalmol Vis Sci. 1997;38(3): 779-782
26. Moya T, Javaloy J, Montés-Micó R, et al. Implantable Collamer Lens for Myopia: Assessment 12 Years After Implantation. J Refract Surg. 2015 Aug;31(8):548-56

27. Chen X, Shen Y, Xu H, et al. One-year natural course of corneal densitometry in high myopic patients after implantation of an implantable collamer lens (model V4c). BMC Ophthalmol. 2020;20(1):50.

28. Shaaban YM, Badran TAF. Three-Year Effect of Phakic Intraocular Lenses on the Corneal Endothelial Cell Density. Clin Ophthalmol.2020;14:149-155.

29. Alfonso J. F., Lisa C., Abdelhamid A., Fernandes P., Jorge J., Montes-Mico R. Three-year follow-up of subjective vault following myopic implantable collamer lens implantation. Graefe's Archive for Clinical and Experimental Ophthalmology. 2010;248(12):1827-1835. doi: 10.1007/ s00417-010-1322-0.

30. Bhandari V., Karandikar S., Reddy J. K., Relekar K. Implantable collamer lens V4b and V4c for correction of high myopia. Journal of Current Ophthalmology. 2015;27(3-4):76-81. doi: 10.1016/j.joco.2016.01.001. [PMC free article] [PubMed] [CrossRef] [Google Scholar]

31. Karandikar S., Bhandari V., Reddy J. Outcomes of implantable collamer lens V4 and V4c for correction of high myopia-a case series. Nepalese Journal of Ophthalmology. 2015;7(2):164-172. doi: 10.3126/nepjoph. v7i2.14967 


\title{
Резиме
}

\section{ПРВИ ИСКУСТВА СО ИМПЛАНТАЦИЈАТА НА ФАКИЧНИ ЛЕК'И ПРИ КОРЕКЦИЈА НА МИОПИЈА ВО РС МАКЕДОНИЈА}

\author{
Билјана Костовска ${ }^{1}$ Јасмина Плунцевиќ Глигороска ${ }^{2}$, \\ Фанка Гилевска ${ }^{1}$, Златко Арнаудовски ${ }^{1}$, Никица Габриќ ${ }^{3}$ \\ ${ }^{1}$ Систина офталмологија - СОБ, Скопје, РС Македонија \\ ${ }^{2}$ Медицински факултет, Институт за физиологија, УКИМ, Скопје, РС Македонија \\ ${ }^{3}$ Клиника Свјетлост, Загреб, Р Хрватска
}

Цел: Анализа на параметрите на видната острина кај пациенти со средна до висока миопија и миопен астигматизам по третман со факични леќи во текот на една година по третманот.

Материјал и методи: Испитувани се 35 пациенти (52 очи) со средна до висока миопија на возраст од 21 до 41 години (10 мажи и 25 жени). Рефракторната мана е коригирана со имплантација на факични леќи, ICL-Vc4. Испитуваните параметри се: најдобра видна острина без корекција за далечина (НДВО) и најдобра видна острина со корекција на далечина (КДВО), манифестна и циклоплегична рефракција, интраокуларен притисок и број на ендотелни клетки. Иследуваните параметри се мерени предоперативно и на четири контролни прегледи во текот на една година по интервенцијата, по 1, 3, 6 и 12 месеци.

Резултати: Кај 17 пациенти имплантирани се факични леќи билатерално, а кај 18 пациенти - монокуларно. НДВО предоперативно доминира со видна острина од 0,9 до 1 (34,62 \%). Постоперативно, по 1 година, доминира видна острина 0,9 до 1 (48,08 \%). Предоперативно доминираше диоптриска јачина од -6 Дспх до - 10 Дспх кај 80,77 \% од пациентите. Постоперативно, по 1 година, доминантно беше застапена диоптриска јачина од -1 Дспх до 0 Дспх кај 78,85 \% од испитаниците. Астигматизмот предоперативно доминираше од -4 Дцил до -2 Дцил, наспроти значително подобрување постоперативно, кога кај 94,23 \% од испитаниците беше присутен со диоптриска јачина од -1 Дцил до 0 Дцил.

Заклучок: Видната острина, диоптријата и астигматизмот покажуваа постепено и значително подобрување на параметрите на видната функција во текот на една година од имплантација на леќите.

Клучни зборови: миопија, астигматизам, видна острина, диоптрија, факични леќи 